\title{
TUJUAN PENCIPTAAN MANUSIA DAN NILAI EDUKASINYA (KAJIAN TAFSIR TEMATIS)
}

\author{
Oleh: Inong Satriadi*
}

\begin{abstract}
Allah must have created universe, included mankind, with particular purposes. Among the purposes are to become His loyal servants, to represent Him as the caliph of the earth: to control and preserve nature and its entity, to be trusted by Him to manage the earth where other creatures were not able to assume such responsibility. The three purposes of creating mankind reflects high educational values. To worship is the main and the only reason for mankind to improve their faith to Allah. As a caliph of the earth, men are supposed to teach others to be come more professional in managing things and trusteeship teaches men to get closer and more responsible to Allah
\end{abstract}

Kata kunci: al-ibadah, al-khalifah, al-amanah, taklif dan keimanan.

\section{PENDAHULUAN}

$\mathrm{U}$ mat Islam berkeyakinan bahwa Allah SWT. adalah Wujud yang Maha Kaya (artinya Dia tidak membutuhkan terhadap sesuatu). Jika demikian mengapa manusia diciptakan? Apa tujuan dari penciptaanNya? Tidakkah hal ini berarti bahwa Allah SWT. adalah Wujud yang melalui tujuan penciptaan manusia membutuhkan atas sesuatu? Kalau seandainya tidak mempunyai tujuan, berarti perbuatan Allah SWT tersebut adalah sia-sia?

Untuk mengatasi persoalan di atas, jawabannya tidak terlepas dari dua pokok proposisi, yaitu; (1). Allah SWT. adalah Wujud yang Maha Sempurna dan tidak membutuhkan apapun dan tidak bergantung kepada siapapun. (2). Perbuatan Allah SWT tidaklah menuju kesia-siaan. Apa yang dilakukanNya pastilah memiliki tujuan, namun tujuan tersebut adalah untuk objek (makhluq) bukan bagi pelaku perbuatan (Khaliq).
Allah SWT Maha Kaya dan Sempurna, tidaklah memiliki kekurangan yang mendasari sebuah tindakan untuk mencapai tujuan. Sebagaimana ulama teologi berkata: "Sesungguhnya perbuatan Allah tidaklah didasari oleh tujuan." Pengertiannya adalah; sesungguhnya manfaat dan tujuan tersebut bukanlah akan kembali pada zat Allah, dikarenakan bagaimana mungkin Dia sebagai Pemilik Kesempurnaan yang Absolut menjadikan dan menutupi diriNya dengan kekurangan.

Allah SWT menciptakan segala sesuatu baik alam maupun manusia tiada yang sia-sia, segalanya memiliki maksud dan tujuan. Sebagaimana firman Allah SWT:

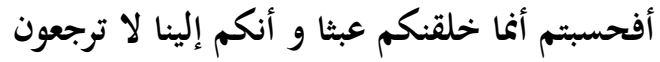

"Maka apakah kamu mengira, bahwa Sesungguhnya Kami menciptakan kamu secara main-main (saja), dan bahwa kamu tidak akan

* Penulis adalah Asisten Ahli dalam Mata Kuliah Hadis dan Ilmu Hadis pada STAIN Batusangkar 
dikembalikan kepada Kami?" (Q.S. Al-Mukminun: 115)

Dalam Surat Ali Imran ayat 191, Allah berfirman:

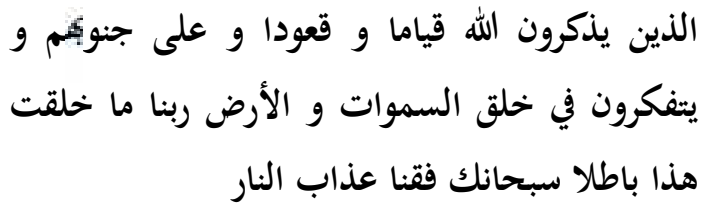

"(yaitu) orang-orang yang mengingat Allah sambil berdiri atau duduk atau dalam keadaan berbaring dan mereka memikirkan tentang penciptaan langit dan bumi (seraya berkata): "Ya Tuhan kami, tiadalah Engkau menciptakan Ini dengan sia-sia, Maha Suci Engkau, Maka peliharalah kami dari siksa neraka”.

Dan dalam surat al-Anbiya' ayat 16, Allah berfirman:

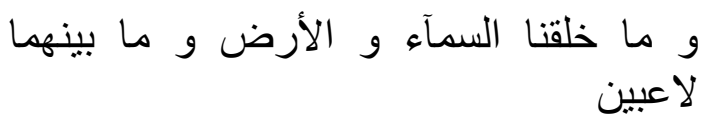

"Dan tidaklah Kami ciptakan Iangit dan bumi dan segala yang ada di antara keduanya dengan bermainmain"

Kandungan ayat-ayat di atas menjelaskan bahwasanya Allah SWT menciptakan langit dan bumi dan apa yang ada di antara keduanya itu adalah dengan maksud dan tujuan yang mengandung hikmat (pelajaran). Tidaklah maksud dan tujuan tersebut kecuali untuk kesempurnaan makhluk bukan bagi kesempurnaan zatNya (Allah SWT). Oleh karena itu, tujuan dari penciptaan, menyampaikan pada semua makhlukNya akan kesempurnaanNya, tanpa manfaat bagiNya sehingga tidaklah menjadikan perbuatan Allah SWT sia-sia.

Adapun tujuan penciptaan manusia tersebut akan diuraikan dalam tulisan ini, termasuk pelajaran dan nilai-nilai kependidikan yang dapat diambil dan dipedomani untuk mengarungi kehidup- an dunia agar bisa selamat sampai ke kampung akhirat.

\section{TUJUAN PENCIPTAAN MANUSIA}

Terdapat beberapa ayat yang memiliki indikasi tentang maksud atau tujuan penciptaan manusia, indikasi tersebut antara lain termuat dalam ungkapan seperti; al-ibadah, al-khilafah (khalifah) dan al-amanah. Ketiga ungkapan kata tersebut tertuang dalam beberapa ayat al-Quran.

\section{Al-Ibadah}

Ungkapan kata al-Ibadah beserta musytaq-nya dalam al-Quran terulang sebanyak 275 kali (M. Fuad Abdul Baqiy, t.th.:560-565). Namun demikian disini hanya akan dipaparkan beberapa ayat yang paling relevan dengan pokok kajian, yaitu:

1. QS Al-Baqarah ayat 21:

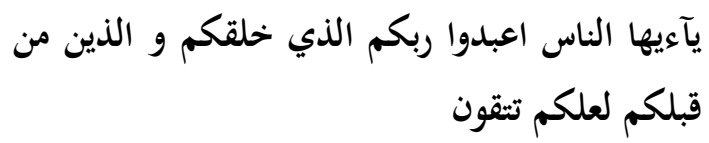

"Hai manusia, sembahlah Tuhanmu yang Telah menciptakanmu dan orang-orang yang sebelummu, agar kamu bertakwa" (QS Al-Baqarah: 21)

2. QS Al-Dzariyat ayat 56:

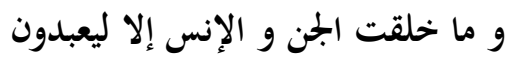

"Dan Aku tidak menciptakan jin dan manusia melainkan supaya mereka mengabdi kepada-Ku” (QS AlDzariyat: 56)

Ayat 21 dari surat al-Baqarah merupakan ajakan untuk menghambakan diri hanya kepada Allah SWT. Ayat-ayat sebelumnya menggambarkan beberapa kelompok manusia, yaitu kelompok orang-orang kafir yang menolak hidayah dan kelompok orang-orang munafik 
yang masih dalam keadaan ragu-ragu. Lalu pada ayat ini manusia diajak untuk memeluk agama tauhid, yaitu dengan menghambakan diri pada Allah SWT, Tuhan satu-satunya, tunduk serta mengikhlaskan diri pada-Nya. Kemudian mereka diingatkan bahwa Allah-lah Tuhan yang telah mencipta, mengatur urusan dengan sunnah-Nya serta menganugerahi mereka hidayah dan jalan untuk bertaqarrub. Maka dari itu tidak ada yang layak dan pantas untuk disembah selain Dia, sebab mensyarikatkan-Nya hanya akan mendatangkan azab dan kehancuran. Lalu dijelaskan bahwa penghambaan diri kepada-Nya serta sesuai dengan ketentuan yang telah digariskan, dapat menghantarkan mereka kepada taqwa, yaitu suatu derajat dimana seseorang dapat merasakan kehadiran Tuhan dalam diri serta memiliki kesadaran ketuhanan yang matang (Al-Maraghiy, t.th. juz I: 63).

Kemudian pada ayat 56 surat alDzariyat dijelaskan bahwa tujuan hakiki dari penciptaan jin dan manusia adalah dalam rangka berubudiyah kepada-Nya. Pada ayat sebelumnya diungkapkan bagaimana pengingkaran orang-orang Quraisy terhadap kerasulan Muhammad bahwa mereka menuding bahwa Muhammad adalah tukang sihir dan sebagainya. Hal itu bukanlah sesuatu yang baru, karena umat-umat sebelumnya juga berbuat serupa ketika menolak para nabi yang diutus. Lalu Nabi Muhammad diajak untuk berpaling dari mereka serta hendaklah ia senantiasa berzikir, sebab itulah yang dapat mendatangkan manfaat bagi kaum beriman.

\section{Al-Khilafah}

Lafaz al-khalifah dan yang semakna dengannya (al-khalifah, alkhalaif dan alkhulafa) terulang dalam alQuran sebanyak 9 kali, yaitu dalam alQuran Surat al-Baqarah ayat 30, surat alAn'am ayat 165, surat al-A'raf ayat 69 dan 74, surat Yunus ayat 14 dan 73,surat al-Namal ayat 62, surat Fathir ayat 39 dan surat Shad ayat 26. (M.Fuad Abdul Baqiy, t.th.: 305). Dalam hal ini akan dikemukakan beberapa ayat yaitu:

1. QS. al-Baqarah ayat 30

$$
\begin{aligned}
& \text { و إذ قال ربك للملئكة إي جاعل في الأرض خليفة } \\
& \text { قالوا أتجعل فيها من يفسد فيها و يسفك الدمآء و ولد } \\
& \text { نحن نسبح بحمدك و نقدس لك قال إي أعلم مالا }
\end{aligned}
$$

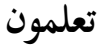

"Ingatlah ketika Tuhanmu berfirman kepada para malaikat: "Sesungguhnya Aku hendak menjadikan seorang khalifah di muka bumi." mereka berkata: "Mengapa Engkau hendak menjadikan (khalifah) di bumi itu orang yang akan membuat kerusakan padanya dan menumpahkan darah, padahal kami senantiasa bertasbih dengan memuji Engkau dan mensucikan Engkau?" Tuhan berfirman: "Sesungguhnya Aku mengetahui apa yang tidak kamu ketahui."

2. QS. al-An'am ayat 165

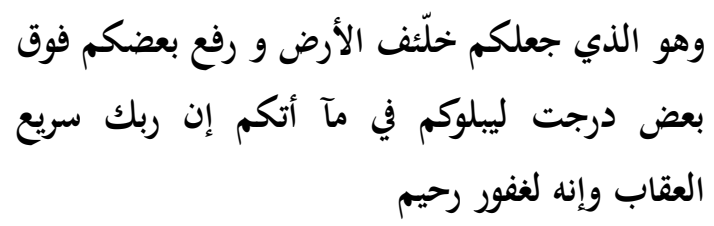

"Dan Dia lah yang menjadikan kamu penguasa-penguasa di bumi dan dia meninggikan sebahagian kamu atas sebahagian (yang lain) beberapa derajat, untuk mengujimu tentang apa yang diberikan-Nya kepadamu. Sesungguhnya Tuhanmu amat cepat siksaan-Nya dan Sesungguhnya Dia Maha Pengampun lagi Maha Penyayang”.

Ayat 30 dari surat al-Baqarah adalah informasi bagi para malaikat bahwa Allah menciptakan khalifah (Adam dan keturunannya) di muka bumi. Ayat ini 
dan ayat-ayat sebelumnya mengungkapkan betapa banyaknya nikmat yang dianugerahkan kepada manusia beriman, dimana mereka berpaling serta menghindarkan diri dari kemaksiatan dan kekafiran sekaligus mengajak manusia lainnya menuju keimanan dan ketaqwaan. Adapun ayat-ayat sesudahnya mengungkapkan bagaimana pertumbuhan manusia dalam bentuk dialog dan diskusi, dimana semua itu menggambarkan rahasia dan hikmah yang agung.

Khalifah adalah pengganti Allah yang mengatur urusan-Nya di tengahtengah kehidupan manusia. Di samping itu khalifah juga dapat dipahami sebagai "suatu regenerasi yang silih berganti dimana mereka bertugas untuk memakmurkan dan mensejahterakan bumi" (Hasan al-Himshi, t.th: 6). Dengan demikian khalifah adalah hamba Allah yang ditugaskan untuk menjaga kemaslahatan dan kesejahteraan dunia.

Adanya "protes" Malaikat kepada Tuhan tentang pengukuhan Adam sebagai khalifah adalah sebuah isyarat dan gambaran bahwa Adam dan keturunannya memiliki keistimewaan yang khas. Namun satu hal yang tidak dapat dipungkiri adalah bahwa diantara keturunan adam terdapat segolongan umat yang lari dari fitrahnya, dimana mereka menyalahi kemaslahatan dan kebijaksanaan serta berbuat kerusakan dan onar dimuka bumi. Namun demikian, Allah akan mengirimkan ilham (wahyu) agar mereka tunduk dan berserah kepada-Nya. Sehingga dengan ikhtiar-nya, mereka mampu mengendalikan dan meminimalisir kecendrungan negatif untuk berbuat kerusakan. Semua itu mengandung hikmah yang sangat tinggi tentang keagungan dan kemahakuasan Sang Khaliq.

Pada ayat ini ditegaskan bahwa Allah akan menobatkan manusia sebagai khalifah di muka bumi. Pengukuhan manusia sebagai khalifah ini mencakup khilafah (kepemimpinan) antar sesama mereka serta khilafah terhadap makhluk lainnya di alam ini. Khilafah antar sesamanya adalah berupa penugasan Allah terhadap beberapa hamba-Nya yang terpilih (nabi dan rasul) untuk menyampaikan syariat (wahyu) kepada manusia. Sedangkan khilafah manusia terhadap makhluk lainnya adalah berupa pengendaliannya terhadap alam secara umum, baik di darat, laut maupun di udara serta juga mencakup bagaimana pengendaliannya terhadap hewan, tumbuh-tumbuhan atau barang-barang tambang yang tersimpan di dalam bumi. Dalam hal ini manusia engan kekuatan akalnya mengatur dan mengendalikan bumi sesuai dengan sunnah yang digariskan. Namun demikian, tidak semua manusia dapat menjalankan misi tersebut, karena diantara mereka banyak yang berbuat kerusakan serta menumpahkan darah, sehingga semua itu akan menganggu stabilitas dan kemakmuran bumi. Namun di balik semua itu terkandung hikmah yang cukup dalam akan kekuasaan dan keagungan Sang Pencipta.

Adanya perusakan dan kemaksiatan serta pertumpahan darah di bumi menimbulkan protes dari Malaikat, padahal mereka adalah makhluk yang taat serta senantiasa mensucikan dan mengagungkan Allah. Maka Allah menjawab banyak hal yang tidak dapat mereka ketahui dibalik semua ciptaan-Nya, sebab Dia menciptakan alam ini penuh dengan hikmah, rahasia dan kesempurnaan yang tidak dapat diketahui oleh semua makhluk. (Al-Maraghiy, t.th, juz 1, 77-81)

QS al-Baqarah/2 ayat 30 ini adalah informasi awal tentang akan dinobatkanya manusia sebagai khalifah, sedangkan QS al-An'am/ 6 ayat 165 adalah penobatan dan pengukuhan manusia sebagai khalifah. Ayat-ayat sebelumnya berbicara dalam konteks pokok-pokok agama (ushul al-din), yaitu penolakan 
terhadap aqidah orang-orang musyrik serta pengingkaran terhadap kemaksiatan. Kemudian dijelaskan bahwa millah Muhammad adalah melanjutkan millah Ibrahim sebelumnya. Shalat, seluruh penghambaan serta hidup dan matinya hanya untuk dan karena Allah SWT. Tidaklah pantas bagi seseorang untuk menghambakan diri kepada yang lain. Lalu ditegaskan lagi bahwa seseorang akan menerima ganjaran sesuai dengan amal dan perbuatannya masing-masing serta seseorang tidak akan mewarisi dosa atau pahala orang lain.

Setelah itu, pada ayat ini Allah ungkapkan bahwa dia telah mengangkat manusia sebagai klala'if al-ardh, di mana mereka melanjutkan kedudukan, pekerjaan dan kekuasaan orang-orang sebelumnya. Dalam menjalankan khilafah tersebut, terdapat ibrah dan pelajaran berharga bagi mereka yang mau merenungi dan mendalaminya. Kemudian Allah mengangkat derajat sebagian mereka dari yang lainnya, sehingga ada yang kaya dan ada yang miskin, ada yang kuat dan ada yang lemah serta ada yang alim dan ada yang bodoh. Semua itu dimaksudkan sebagai ujian dan cobaan dimana kelak mereka akan memperoleh balasan sesuai dengan amal dan perbuatan masing-masing. Itu semua adalah sunnah yang digariskan Allah bagi kehidupan dunia. Kemudian ditegaskan bahwa azab dan iqab Allah siap menanti bagi mereka yang kafir, menolak kenabian (Muhammmad), melangar syari'at serta menyimpang dari sunnah yang telah diciptakan untuk kemaslahatan dan kedamaian dunia. Azab itu akan berlaku baik di dunia maupun di akhirat. Azab dunia adalah seperti kecelakaan dan kehancuran, akal yang tidak berfungsi untuk kebaikan, tidak punya harga diri, kehilangan harta, keresahan dan lain-lain sebagainya.

Kemudian Allah memberi berita gembira bahwa Dia Maha Pengampun bagi mereka yang bertaubat serta senantiasa mengasihi kaum beriman dan orang-orang yang senantiasa berbuat kebajikan.(Al-Maraghiy, t.th.juz III: 9394).

\section{Al-Amanah}

Ungkapan kata al-amanah terulang dalam al-Quran sebanyak 6 kali yang juga terdapat dalam enam ayat. Kata tersebut dalam bentuk mufrad (tunggal/ singular) terulang sebanyak dua kali, sedangkan dalam bentuk jamak/ plural terulang sebanyak empat kali. Ayat-ayat tersebut terdapat dalam Al-Quran surat al-Baqarah ayat 283, surat al-Nisa'ayat 58 , surat al-Anfal ayat 27 , surat alMukminun ayat 8 , surat al-Ahzab ayat 72 dan surat al-Ma' arij ayat 32 .

Dalam tulisan ini akan dikemukakan QS al-Ahzab ayat 72 mengingat bahwa ayat ini sangat terkait erat dengan pokok permasalahan, khususnya tentang tugas yang diemban oleh manusia. Ayat tersebut ialah:

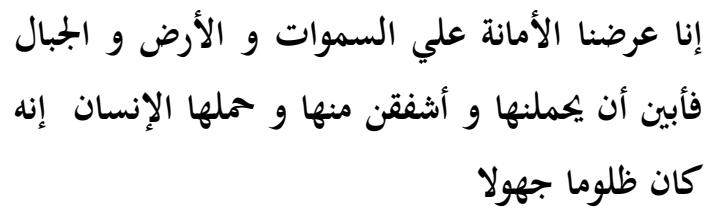

"Sesungguhnya kami Telah mengemukakan amanat kepada langit, bumi dan gunung-gunung, Maka semuanya enggan untuk memikul amanat itu dan mereka khawatir akan mengkhianatinya, dan dipikullah amanat itu oleh manusia. Sesungguhnya manusia itu amat zalim dan amat bodoh"

Dua ayat sebelumnya mengutarakan perintah Allah SWT kepada kaum beriman agar senantiasa bertaqwa kepada Allah SWT serta juga senantiasa mengungkapkan perkataan yang benar (qaulan sadidan). Dengan mematuhi kedua hal tersebut, Allah akan mengarahkan kaum beriman pada amal 
shaleh, mengampuni dosa serta menjauhkannya dari azab. Selanjutnya Allah jelaskan bahwa siapa saja yang mentaati Dia dan Rasul-Nya, maka kelak mereka akan memperoleh balasan yang agung serta kemuliaan di hari akhir. Dari hal ini dapat disimpulkan bahwa dalam kedua ayat ini terdapat dua buah perintah Allah SWT, yaitu berkata benar dan senantiasa berbuat kebaikan. Dengan melakukan kedua hal ini berarti mereka telah bertaqwa kepada-Nya sekaligus menjauhi iqab-Nya. Kemudian Allah memotivasi dan memberikan kabar gembira bagi kaum beriman dengan menjanjikan dua hal, pertama, Allah akan memuliakan amalan mereka, sebab taqwa dengan sendirinya akan memperindah amalan seseorang, sedangkan amalan akan mengangkat kedudukan pelakunya ke tempat yang lebih tinggi, dimana disana mereka akan memperoleh kesenangan dan kebahagian yang abadi. Kedua, Allah SWT menjanjikan mereka berupa ampunan. Di samping itu, Allah juga akan menutup aibnya serta juga terbebas dari azab yang maha dahsyat.(Al-Maraghiy,t.th. juz VIII: 45).

Selanjutnya pada ayat 72 ini Allah SWT menjelaskan tentang bagaimana susah dan sulitnya menanggung beban dalam rangka mencapai taqwa, qaulan sadidan serta ketaatan kepada Allah dan Rasul-Nya. Adapun kaitan (munasabah) yang signifikan antara ayat ini dengan kedua ayat sebelumnya adalah bahwa pada dua ayat sebelumnya Allah SWT menerangkan betapa mulia dan agungnya ketaqwaan dan ketaatan kepadaNya, lalu pada ayat ini Allah jelaskan bagaimana susahnya mengemban amanah yang diberikan kepada makhluq-Nya hingga langit, bumi dan gunung-gunung yang begitu gagah dan kekar menolak untuk mengemban amanah tersebut.

Kemudian pada ayat selanjutnya Allah SWT menerangkan bahwa Dia akan mengazab kaum munafik dan musyrik serta memberi ampunan bagi kaum beriman. Adapun kaitan ayat ini dengan ayat sebelumnya adalah bahwa tidak banyak manusia yang mampu dan lulus dalam menjalankan amanah yang begitu berat sebagaimana diterangkan pada ayat sebelumnya.

Kata (yang terdapat pada ayat 72) adalah ungkapan kesiapan bagi langit dan bumi. (Al-Maraghiy,t.th. juz VIII: 45). Selanjutnya kata berarti (menjadikan atau menganggap sesuatu menjadi sedikit) (Ibnu Zakariya, 1994: 384).Al-Raghib al-Asfahaniy menerangkan bahwa kata ini "menggambarkan sesuatu yang sangat banyak" (AlAsfahaniy, 1999: 131). Jika kedua pendapat ini dipadukan maka akan melahirkan makna yang sinergik dan searah, dimana maksudnya adalah bahwa kata ini memiliki makna sesuatu yang berat atau banyak, lalu ia dianggap sedikit atau ringan sehingga dapat dipikul atau diangkat. Hal ini senada dengan ayat dimana al-amanah adalah sesuatu yang berat lalu dengan rasa percaya diri yang cukup tinggi manusia berusaha untuk memikulnya dengan mengangap bahwa hal itu ringan baginya atau mampu untuk ia pikul.

Pada ayat ini Allah menjelaskan bahwa sesungguhnya Dia tidaklah menciptakan langit dan bumi dimana keduanya memiliki fisik yang besar serta kekuatan terpendam untuk mampu mengemban beban taklif, yaitu berupa perintah, larangan serta kearifan dalam menjaga kemaslahatan agama dan dunia. Kenyataan adalah bahwasanya Allah SWT memberikan beban itu semua kepada manusia, yaitu untuk menerima dan menjalankannya plus dengan segala kekurangan yang ia miliki. Di samping itu, manusia juga sering dikalahkan oleh hasutan yang senantiasa membawa pada nafsu amarah, sehingga manusia sering berbuat zalim sesamanya. Selanjutnya manusia juga sering ditunggangi oleh 
nafsu syahwat serta kecendrungan untuk lepas tangan dari tanggung jawab, sehingga mendatangkan akibat fatal dan kerusakan dari semua apa yang mereka lakukan. Maka dari itu Allah SWT membebankan taklif kepada manusia agar ia mampu mematahkan semua bentuk kekerasan (kekejaman), meminimalisir pengaruhnya serta membendung hawa nafsu agar manusia terhindar dari perbuatan dan kejadian yang membawa kehancuran (Al-Maraghiy, t.th. juz VIII: $45)$.

Selain pendapat di atas, ada juga yang memahami bahwa yang dimaksud dengan dalam ayat tersebut adalah , sebab ketaatan itu harus ada sebagaimana halnya dengan al-amanah dimana ia harus ditunaikan dan dibayarkan. (al-Zamakhsyariy,1995 juz III: 546-547).

Dari ayat tersebut ada dua hal yang dapat diilustrasikan. Pertama, ayat ini menggambarkan akan ketaatan dan ketundukan langit, bumi dan gununggunung (al-jumadat) kepada Allah SWT. Kondisi ini memungkinkan bagi langit, bumi ataupun gunung-gunung untuk mengemban tugas yang cukup berat tersebut, sebab mereka tidak memiliki kecendrungan negatif, melenceng atau kecendrungan untuk berkhianat. Hal ini membuat mereka lebih pantas dan layak dalam mengemban serta memikul tugas itu. Adapun manusia, keadaannya tidak persis sama dan setaat al-jumadat tersebut, sehingga pada dasarnya manusia tidaklah pantas untuk mengemban tugas yang cukup berat tersebut. Keunggulan al-jumadat dalam mengemban tugas tersebut adalah majas atau kiasan akan ketundukan dan ketaatannya. Lalu tugas berat tersebut diemban oleh manusia, akhirnya manusia diberi gelar sebagai makhluq yang zalim karena ia seringkali lalai dalam menunaikan amanah. Di samping itu ia juga diberi gelar sebagai makhluq yang bodoh karena ia seringkali tersalah dan khilaf dalam menjalankan amanah.

Adapun ilustrasi kedua dari ayat ini adalah berupa gambaran atau kiasan betapa beratnya beban yang diemban manusia, dimana pada mulanya beban berat ini akan dipikulkan kepada langit, bumi dan gunung-gunung yang kuat, kokoh dan tangguh, namun mereka menolak dan enggan untuk memikul beban itu. Akhirnya beban berat tersebut diemban oleh manusia yang sangat lemah dan loyo. Selanjutnya Allah SWT menegaskan bahwa manusia adalah makhluq yang zalim dan bodoh, sebab manusia sering tidak mampu atau tidak sempurna dalam menjalankan amanah serta sering berkhianat dengan jaminan dan janji yang diberikan.(al-Zamakhsyariy,1995 juz III: 546-547).

Kemudian ada juga yang memahami bahwa al-amanah adalah "sesuatu yang dititipkan kepada orang agar dijaga dan dipelihara untuk kemudian dikembalikan lagi kepada yang menitipkan sebelumnya". Al-Amanah yang disebutkan dalam ayat ini adalah "sesuatu yang dipercayakan Allah SWT kepada manusia agar dipelihara dan dijalankan dengan penuh ketekunan dan istiqomah untuk kemudian hari dikembalikan kepada Allah yang telah menitipkan semuanya kepada manusia”.(Thaba Thaba'iy, 1991 juz VII: 254).

Berdasarkan penafsiran di atas, alamanah dalam ayat tersebut juga bisa diumpamakan sebagai"ujian dan tanggungjawab". Hal ini seiring dengan taklif (pemberian kewajiban oleh Allah SWT), pemberian hak kebebasan bertindak dan tanggung jawab dalam menentukan pilihan. Alam seisinya selain manusia bergerak sesuai dengan ketentuan hukum alam, tanpa harus mempertanggungjawabkan perbuatannya. Seandainya langit menghantam bumi dengan semburan gunturnya dan meng- 
hasilkan curahan air alirannya, lalu tanaman dan pekarangan merenggas karena kekeringan, atau seandainya langit kembali mencurahkan hujan lalu bumi hidup kembali setelah mati, tetap saja mereka tidak akan ditanya macammacam mengenai perbuatannya itu. Seandainya bumi bergoncang, lalu segala yang hidup musnah, atau seandainya gunung-gunung hancur berhamburan dan pecahan-pecahannya menimpa suatu negeri yang aman dan sentosa. Maka langit, bumi dan gunung-gunung tersebut tidak akan dihisab atas segala perbuatannya, yang baik maupun ulah buruknya tersebut. Hanya manusialah yang diminta pertanggungjawabannya atas segala perbuatannya, dihisab untuk menerima imbalan pahala dan balasan azab. Tidak seorang pun dapat menggantikan kedudukan orang lain untuk mempertanggungjawabkan perbuatannya dan tidak seorang pun lolos tanpa pembalasan.(Aisyah Binti Syati', 1999: 5253).

Dengan demikian, ada dua hal menarik terkait dengan makna al-amanah dalam al-Quran, khususnya pada ayat yang sedang dibahas ini yaitu: al-tha'ah (taat) dan tanggung jawab. Makna altha'ah nampaknya lebih melihat kepada korelasi (munasabah) pada ayat-ayat sebelum dan sesudahnya. Sedangkan makna kedua (tanggung jawab) lebih mengarah kepada kesatuan dan keutuhan makna pada satu ayat terkait, sebab tanggung jawab ini amat terkait dengan pembalasan (hisab) di akhirat kelak. Adapun makhluq yang akan mempertanggungjawabkan seluruh amal perbuatannya adalah manusia dan ini juga terkait dengan misinya sebagai khalifah di bumi. Maka dari itu penulis lebih cenderung kepada kedua pendapat tersebut. Namun demikian, bukan berarti kiranya pendapat yang lainnya harus ditolak atau tidak dipakai sama sekali, sebab semuanya sangat terkait serta saling menguatkan dan menyempurnakan.

\section{NILAI EDUKASI DALAM TUJUAN PENCIPTAAN MANUSIA}

Tujuan penciptaan manusia yang pertama adalah untuk mengabdi dan menghambakan diri kepada Allah SWT (ibadah). Tujuan ini mendidik manusia untuk senantiasa meningkatkan keimanan dan ketaqwaan kepada Allah SWT, karena ibadah dapat dikatakan sempurna apabila dilaksanakan atas dasar landasan iman kepadaNya. Semakin tinggi tingkat keimanan seseorang, maka semakin tinggi pula kualitas ibadah yang dilakukan. Allah SWT dan RasulNya memerintahkan seseorang untuk senantiasa meningkatkan dan memperbaharui keimanan, karena iman dapat mengalami pasang naik maupun pasang surut. Sabda Rasulullah :

$$
\begin{aligned}
& \text { عن أبي هريرة أن النبي صلي الله عليه وسلم قال : " } \\
& \text { جددوا إيمانكم "قالوا: كيف نجدد إيماننا ؟ قال : " } \\
& \text { قولوا : لا إله إلا الله (رواه أحمد) }
\end{aligned}
$$

Tarbiyah Imaniyah (mendidik iman) dapat dilakukan dengan tiga cara, yaitu; pertama, selalu mentadaburi (mengamati, mempelajari, menghayati) tanda-tanda kekuasaan Allah Dzat Pencipta serta keluasan rahmat dan hikmah perbuatan-Nya. kedua, selalu mengingat kematian yang penuh kepastian. ketiga, mendalami fungsi semua jenis ibadah sebagai salah satu cara mendidik iman. caranya dengan banyak mengerjakan amal shalih yang sendi utamanya adalah keikhlasan, juga memperbanyak do'a dan harapan kepada Allah SWT semata, menghindari riya' dalam berbuat dan bertindak, mencintai firman Allah, berkeyakinan bahwa kelak akan berjumpa langsung dengan Allah SWT, dan terakhir melanggengkan rasa syukur dalam keadaan apapun. 
Tujuan penciptaan manusia yang kedua adalah Allah menempatkan manusia sebagai khalifah fi al-ardh, yaitu manusia yang diberi derajat tinggi untuk mengatur, mengelola dan mengolah semua potensi yang ada dimuka bumi. Keadaan ini mendidik manusia untuk selalu berfikir kearah pengembangan pengelolaan seluruh potensi yang ada sehingga tercipta sumber daya manusia (SDM) yang professional. Terpilihnya manusia sebagai pemimpin di muka bumi mendidik mereka untuk memberikan takaran yang seimbang bagi manusia itu sendiri bahwa di satu sisi ia harus bertanggungjawab terhadap dirinya, masyarakat dan alam semesta, dan di sisi lain ia tidak dapat melepaskan dirinya sebagai hamba yang harus patuh terhadap cosmos Ilahiyyah.(Armai Arief: 2005, 166)

Peran manusia sebagai hamba Allah SWT yang ditugaskan untuk menjaga kemaslahatan dan kesejahteraan dunia termasuk manusia (khalifah), mendidik mereka untuk bisa hidup bermasyarakat. Tarbiyah Ijtimaiyah (pendidikan kemasyarakatan) yang baik adalah orang yang selalu memperhatikan perasaan orang lain. Seorang muslim dalam masyarakat tidak dibenarkan menyakiti saudaranya walaupun hanya dengan menebar bau yang tidak enak. Ibnu Qayyim berpendapat, tidak cukup hanya tanpa menyakiti perasaan saja, seorang muslim harus mampu membahagiakan dan menyenangkan hati saudara-saudara di sekitarnya.
Tujuan penciptaan manusia yang ketiga adalah mengemban amanah, yaitu kesanggupan manusia memikul beban taklif yang diberikan oleh Allah SWT. Hal ini mendidik orang-orang beriman supaya selalu memelihara amanah dan mematuhi perintah tersebut. Amanah yang sudah ditetapkan tersebut agar tidak dikhianati, baik amanah dari Allah SWT dan RasulNya maupun amanah antara sesama manusia. Di samping itu, manusia juga dididik untuk bertanggungjawab atas segala perbuatannya. Karena kelak di akhirat akan dihisab untuk menerima imbalan pahala atau balasan azab.Tak seorang pun dapat menggantikan kedudukan orang lain untuk mempertanggungjawabkan perbuatannya. Dan tak seorang pun lolos tanpa pembalasan. (Aisyah Bintu Syati, 1999:53)

\section{KESIMPULAN}

Manusia diciptakan Allah SWT bertujuan di antaranya adalah untuk beribadah kepada-Nya dan menjadi khalifah Allah SWT di muka bumi (Khalifah Allah fi al-Ardh). Dalam menjalankan kedua misi tersebut, manusia juga diberi beban yang cukup berat, yaitu berupa al-amanah atau beban takhlif. Semua itu akan dipertanggungjawabkan di hadapan Allah SWT berupa pahala dan dosa atau balasan syorga dan neraka sesuai dengan kadar al-ibadah, al-khalifah dan al-amanah yang ia lakukan selama hidup di dunia. 


\section{DAFTAR PUSTAKA}

Abu al-Qasim Jar Allah Muhammad ibn Umar ibn Muhammad alZamakhsyariy. 1995. al-Kasysyaf an Haqa'iq al-Tanzil wa al-'Uyun al- Aqawil fi Wujuh al-Ta'wil, Beirut: Dar al-Fikr.

Abu Husain Ahmad ibn Faris ibn Zakariya. 1994. Mu'jam alMaqayis fi Lughah, Beirut: Dar alFikr.

Afif Muhammad. 1998. Islam "Mazhab” Masa Depan, Menuju Islam non Sektarian, Bandung: Pustaka Hidayah

Ahmad Musthafa al-Maraghiy, 1074. Tafsir al-Maraghiy, Mesir: Musthafa al-Bab al-Halabiy.

Aisyah Bintu Syati. 1999. Manusia dalam Perspektif al-Quran, Penterjemah: Ali Zawawi, judul asli: Maqal fi al-Insan, Dirasah Quraniyyah, Jakarta: Pustaka Firdaus.

Armai Arief. 2005. Reformulasi Pendidikan Islam, Jakarta: CRSD Press,
Fazlur Rahman. 1996. Tema Pokok alQuran, judul asli, Major Themes of The Quran, penerj. Anas Mahyuddin, Bandung: Pustaka,

Muhammad Fuad Abdul Baqi. 1992. Mu'jam al-Fahrasy li al-Fazh alQuran al-Karim, Beirut: Dar alFikr,

Muhammad Hasan al-Himshi, Mufradat al-Quran, Tafsir wa Bayan, Beirut: Dar al-Fikr, t.th

Muhammad Husein Thaba Thaba'iy. 1991. al-Mizan fi Tafsir al-Quran, Beirut: Mu'assasah a-A'lami li alMathbu'at,

Raghib al-Ashfahaniy, al-Mufradat $f i$ Gharib al-Quran, Beirut: Dar alMa'rifah, 502

Yasien Mohamed, 1997. Islam yang Suci, Konsep Fitrah dalam Islam, judul asli, Fitra, The Islamic Concept of Human Nature, Penerj. Mashur Abadi, Bandung: Mizan 